\title{
The Impact of Daily Habits on the Physical Activity Levels of Children Aged 7-10: An Investigation
}

\author{
Halil Çolak \\ Faculty of Sport Sciences, Giresun University, Turkey
}

Copyright $\subseteq 2019$ by authors, all rights reserved. Authors agree that this article remains permanently open access under the terms of the Creative Commons Attribution License 4.0 International License

\begin{abstract}
The aim of this study is to investigate the impact of the body mass index in children between the ages of $7-10$ on their physical activity levels. The target population of the study is children between the ages of 7 and 10. The sample population consists of children between the ages of 7 and 10 who continue their primary education in various primary schools in Cankaya district of Ankara province in Turkey. 508 students voluntarily participated in the survey. The physical activity level was measured using the pedometer device for 3 days of the week and the mean was identified by taking the average. The questionnaire developed by the researcher was conducted to determine the daily life habits of the sample population. Statistical calculations were made using the SPSS package program 23. As a result of the Anova analysis performed according to the age variable, a significant difference was found between the children's physical activity levels at $\mathrm{p}<0.01$ level. There is a significant negative correlation between physical activity level and body mass index $(r=-0,730)$ at the $\mathrm{p}<0,001$ level. A significant negative correlation was found between the level of physical activity and daily use of computer or smartphone $(r=-0125)$ at level $\mathrm{p}<0.05$. A significant negative correlation was found between the level of physical activity and the habit of playing on the playground or on the street $(r=-0,094)$ at level $p<0.05$. As a result, it can be said that the children's body mass index values are healthy and their levels of physical activity is found to be vigorously active. In addition, it is thought that there is a positive increase in physical activity level by decreasing the screen time by using television, computer and phone less.
\end{abstract}

Keywords Physical Activity, Daily Habits, Children, Child, Every Day Life

\section{Introduction}

Physical activity is the bodily movement produced by skeletal muscles that results in energy expenditure. All kinds of physical activity result in energy expenditure. Depending on the nature of the studies, physical activity can be classified in different ways (aerobic, anaerobic, or can be varied, such as static, dynamic) [1]. In a large majority of society, physical activity is perceived as synonymous with the word "sport". However, physical activity is defined as activities that occur by using energy of muscles and joints in daily life, increases heart and respiratory rate and result in fatigue at different intensities. In this context, as well as sports activities, exercise, play and various activities during the day are accepted as physical activity [2].

Childhood is a period of rapid growth and development. In this period, meeting the increasing nutrients requirements is an important factor in the prevention of chronic diseases in adulthood. Healthy eating and lifestyle habits are shaped during childhood and they may become permanent habits over time. These habits are essential to promote and protect health. Being physically inactive, consuming fast food type of foods frequently, spending time on television and computer for a long time and consuming foods with high calorific value during these periods are the most important factors affecting being overweight and obesity in children. Regular and balanced eating habits and regular physical activity are the most important factors for the preservation and improvement of health. The development of healthy living habits during childhood can be promoted by education starting from childhood [3].

A lifestyle that lacks physical activities, affect disability and mortality. The fact that regular physical activity can prevent or delay different chronic diseases is well understood today [4]. Baltaci states that regular physical activity plays a significant role in the healthy growth and development of children and young people, breaking of unhealthy habits in socialization [5], in the protection of adults from various chronic diseases or in the treatment of these diseases or to ensure an active lifestyle in old age. In other words, to ensure an increasing quality of life throughout one's life [6]. 
In the lack of physical activity, obesity may occur. According to Simsek (2005), obesity is an energy metabolism disorder that can cause physical and mental problems caused by excessive fat storage in the body[7]. Consuming more energy than burned is the most important cause of obesity [8]. The regulation of body fat tissue and the etiology of obesity are multifactorial and are affected by genetic structure, environmental stimulation and developmental milestones [9]. Changes in dietary and activity habits increase the frequency of obesity. Especially in children genetically predisposed to obesity, obesity is known to occur with the influence of environmental factors [8]. It has been shown in various studies that the nutrient intake of the child is shaped by feeding habits during infancy, and that the feeding characteristics of their parents and the circles of their family can cause obesity [10]. On the other hand, obesity and being overweight are closely associated with a sedentary lifestyle and lack of physical activity [11].

This study was conducted to investigate the impact of daily habits of children between the ages 7 and 10, on their physical activity levels.

\section{Data and Method}

\section{Study Group}

The research population is composed of children studying in primary schools in Ankara in the 2017-2018 academic year, while the sample consists of students studying in primary schools in Cankaya district. The study includes 508 students aged 7-10 who volunteered to participate in this study. The required permissions were taken from the school directorates and the parents of the students before starting the research.

\section{Height and Weight}

The body weight was measured with a Seca electronic scale with a precision of $0.1 \mathrm{~kg}$, while its length was measured with a $0.01 \mathrm{~cm}$ precision Seca digital scale. The student was required to wear shorts and a T-shirt, and remove their shoes while the height and body weight were taken.

\section{Survey}

The questionnaire used in the study was developed by the researcher and related to the following variables. Participants were asked to report their daily sleep periods, time spent on TV and computer, transport to school (school bus, on foot) and whether they consumed junk food outside of meal times.

\section{BMI (Body Mass Index)}

BMI was obtained by proportioning the body weight to the square of the height in meters. Body Weight $(\mathrm{kg}) /$ Height $(m)^{2}$ formula was used Gunes [12], Atamer [13], Larsson [14].Body composition was evaluated according to the BMI criteria determined by Cole et al. for children from 2 to 18 years of age [15].

\section{Measurement of Physical Activity Level}

Physical activity levels were measured on 2 weekdays and 2 weekend days using the Kenz Lifecorder pedometer. Pedometers were placed on the hip and they were checked against any problems by taking a few steps before the measurements. They were made to wear these pedometers after getting up and kept them until going to bed. Daily step standards graphics were developed for youth by Tudor Locke et al. [16].

\section{Statistical Analysis}

SPSS 23.0 Statistical package was used for analyzing the data. Through the analysis of the data, percentage, frequency, T-test for independent samples, single factorial variance analysis (ANOVA), Turkey (HSD) test, and correlation analysis have been used.

Table 1. Body Mass Index Classification

\begin{tabular}{cccccc}
\hline Too low & Borderline & Good Fitness & Overweight & Obesity & \\
\hline 12 or less & $13-16$ & $17-25$ & $26-30$ & $30+$ & BMI (weight $/$ height $)^{\text {2nd }}$ ) \\
\hline
\end{tabular}

Table 2. Physical Activity Levels Classification

\begin{tabular}{ccccc}
\hline Sedentary lifestyle & Low active & Somewhat active & Active & Very active \\
\hline$<5000$ & $5000-7499$ & $7500-9999$ & $10000-12499$ & $>12500$ \\
\hline
\end{tabular}




\section{Findings}

When the physical activity levels of the children were examined; 3,9\% reported that they were active at some times, $35,8 \%$ had an active life and $60,2 \%$ were highly active. Sedentary behaviors or low levels of physical activities have not been observed in the sample. According to the Body Mass Index; 5.9\% were underweight, $61.8 \%$ were borderline, $31.1 \%$ were healthy weighted and $1.2 \%$ were overweight.

Table 3. Body Mass Index (BMI) and Physical Activity Levels

\begin{tabular}{cccc}
\hline \multirow{2}{*}{$\mathrm{N}=508$} & & $\mathrm{f}$ & $\%$ \\
\hline \multirow{3}{*}{ Level of Physical Activity } & Somewhat active & 20 & 3,9 \\
\cline { 2 - 4 } & Active & 182 & 35,8 \\
\cline { 2 - 4 } & Highly active & 306 & 60,2 \\
\cline { 2 - 4 } Body Mass Index & Too Low & 30 & 5,9 \\
\cline { 2 - 4 } & Borderline & 11,8 & 31,1 \\
\cline { 2 - 4 } & Good Fitness & 6 & 1,2 \\
\hline
\end{tabular}

Table 4. According to the age of the children descriptive variables, ANOVA and Tukey HSD results

\begin{tabular}{|c|c|c|c|c|c|c|c|}
\hline \multirow{5}{*}{ Height } & Age & $\mathrm{N}$ & Arithmetic mean & Standard Deviation & \multirow{5}{*}{101,074} & \multirow{5}{*}{$0,000 * * *$} & \multirow{5}{*}{\begin{tabular}{|c} 
Tukey HSD \\
7-8 years old $* * *$ \\
7-9 years old $* * *$ \\
7-10 years old $* * *$ \\
8-9 years old $* * *$ \\
8-10 years old $* * *$ \\
9-10 years old $* * *$
\end{tabular}} \\
\hline & 7 & 138 & 1,2634 &, 05632 & & & \\
\hline & 8 & 157 & 1,2962 & 04558 & & & \\
\hline & 9 & 100 & 1,3365 &, 05120 & & & \\
\hline & 10 & 113 & 1,3697 & ,05296 & & & \\
\hline \multirow{4}{*}{ Weight } & 7 & 138 & 24,86 & 4,985 & \multirow{4}{*}{39,307} & \multirow{4}{*}{$0,000 * * *$} & \multirow{4}{*}{$\begin{array}{c}\text { 7-8 years old * } \\
\text { 7-9 years old } * * * \\
\text { 7-10 years old } * * * \\
\text { 8-9 years old } * * \\
\text { 8-10 years old *** } \\
\text { 9-10 years old } * *\end{array}$} \\
\hline & 8 & 157 & 27,12 & 6,918 & & & \\
\hline & 9 & 100 & 30,28 & 7,118 & & & \\
\hline & 10 & 113 & 33,35 & 7,264 & & & \\
\hline \multirow{4}{*}{ Body Mass Index } & 7 & 138 & 15,5142 & 2,54452 & \multirow{4}{*}{12,360} & \multirow{4}{*}{$0,000 * * *$} & \multirow{4}{*}{$\begin{array}{c}\text { 7-9 years old } * * \\
7-10 \text { years old } * * * \\
8-10 \text { years old } * * *\end{array}$} \\
\hline & 8 & 157 & 16,0042 & 3,21784 & & & \\
\hline & 9 & 100 & 16,8128 & 3,04694 & & & \\
\hline & 10 & 113 & 17,6573 & 3,05328 & & & \\
\hline \multirow{4}{*}{ Physical activity level } & 7 & 138 & 13163,67 & 1430,780 & \multirow{4}{*}{5,169} & \multirow{4}{*}{$0,002 * *$} & \multirow{4}{*}{$\begin{array}{l}\text { 7-10 years old** } \\
8-10 \text { years old * }\end{array}$} \\
\hline & 8 & 157 & 13011,29 & 1567,007 & & & \\
\hline & 9 & 100 & 12841,40 & 1645,772 & & & \\
\hline & 10 & 113 & 12411,08 & 1714,330 & & & \\
\hline \multirow{4}{*}{ Daily Sleep Duration } & 7 & 138 & 7,7899 & 2,05562 & \multirow{4}{*}{0,082} & \multirow{4}{*}{0,970} & \multirow{4}{*}{---} \\
\hline & 8 & 157 & 7,7834 & 1,81983 & & & \\
\hline & 9 & 100 & 7,6800 & 1,84708 & & & \\
\hline & 10 & 113 & 7,7434 & 1,75651 & & & \\
\hline \multirow{4}{*}{$\begin{array}{c}\text { Daily TV Viewing } \\
\text { Time }\end{array}$} & 7 & 117 & 2,2137 & 1,25828 & \multirow{4}{*}{0,179} & \multirow{4}{*}{0,910} & \multirow{4}{*}{--- } \\
\hline & 8 & 137 & 2,1168 & 1,18858 & & & \\
\hline & 9 & 84 & 2,1190 & 1,09109 & & & \\
\hline & 10 & 102 & 2,1765 & 1,17239 & & & \\
\hline
\end{tabular}




\begin{tabular}{|c|c|c|c|c|c|c|c|}
\hline \multirow{4}{*}{$\begin{array}{l}\text { Daily Computer or } \\
\text { Smartphone Usage }\end{array}$} & 7 & 81 & 2,3086 & 1,48022 & \multirow{4}{*}{1,252} & \multirow{4}{*}{0,291} & \multirow{4}{*}{---} \\
\hline & 8 & 103 & 2,6990 & 1,92931 & & & \\
\hline & 9 & 60 & 2,7500 & 1,91005 & & & \\
\hline & 10 & 72 & 2,7917 & 1,65246 & & & \\
\hline \multirow{4}{*}{$\begin{array}{l}\text { Transportation to } \\
\text { School }\end{array}$} & 7 & 138 & 1,5145 &, 50161 & \multirow{4}{*}{0,307} & \multirow{4}{*}{0,820} & \multirow{4}{*}{---} \\
\hline & 8 & 157 & 1,5223 & ,50110 & & & \\
\hline & 9 & 100 & 1,5700 & ,49757 & & & \\
\hline & 10 & 113 & 1,5133 &, 50205 & & & \\
\hline \multirow{4}{*}{$\begin{array}{l}\text { The habit of } \\
\text { consuming snacks }\end{array}$} & 7 & 138 & 1,3406 & ,47563 & \multirow{4}{*}{0,596} & \multirow{4}{*}{0,618} & \multirow{4}{*}{---} \\
\hline & 8 & 157 & 1,4140 & ,49413 & & & \\
\hline & 9 & 100 & 1,3800 & ,48783 & & & \\
\hline & 10 & 113 & 1,3628 & ,48296 & & & \\
\hline \multirow{4}{*}{$\begin{array}{c}\text { The habit of playing in } \\
\text { the playground or in } \\
\text { the street }\end{array}$} & 7 & 138 & 1,2826 & ,45191 & \multirow{4}{*}{3,414} & \multirow{4}{*}{$0,017^{*}$} & \multirow{4}{*}{$\begin{array}{l}8-10 \text { years old * } \\
9-10 \text { years old* }\end{array}$} \\
\hline & 8 & 157 & 1,2739 & ,44738 & & & \\
\hline & 9 & 100 & 1,2500 & ,43519 & & & \\
\hline & 10 & 113 & 1,4248 & ,49651 & & & \\
\hline
\end{tabular}

$\mathrm{p}<0,05^{*} \quad \mathrm{p}<0,01 * * \quad \mathrm{p}<0,001 * * *$

Significant differences were found between the height variable of children at $\mathrm{p}<0.001$ level according to age. The difference is caused by the differences at $p<0,001$ level in the 7-8 age group, 7-10 age group, 8-9 age group, 8-10 age group and 9-10 age group. Significant differences were found between the groups in terms of weight at $p<0.001$ level, whereas the groups with differences were 7-8 age group ( $p<0,05), 8-9$ age group and 9-10 age group $(p<0,01)$, 7-9 age group, 7-10 age group and 8-10 age group $(\mathrm{p}<0.001)$. Significant differences were found in body mass index at $p<0.001$ level. The difference was due to the differences in the 7-9 age group, $\mathrm{p}<0.01,7-10$ age group and 8-10 age group $\mathrm{p}<0.001$ level. As a result of the Anova analysis performed according to the age variable, a significant difference was found between the children's physical activity levels at $p<0.01$ level. According to the age variable, there was a significant difference in $p<0.05$ level between the habit of playing in the street and playing on the playground. No differences have been observed between daily sleep time, daily television viewing time, daily use of computer or smartphone and the habit of consuming junk food.
There is a significant negative correlation between physical activity level and body mass index $(r=-0,730)$ at the $p<0,001$ level. A significant negative correlation was found between the level of physical activity and daily use of computer or smartphone $(r=-0125)$ at level $p<0.05$. A significant negative correlation was found between the level of physical activity and the habit of playing on the playground or on the street $(r=-0,094)$ at level $p<0.05$. A significant negative correlation was found between the habit of consuming snacks and daily television viewing time $(r=-0,106)$ and the habit of using a daily computer or smartphone $(r=-0,197)$ at the level $p<0,05$.

According to the findings shown in Table $6,0.4 \%$ of 7 year-old children were identified as sometimes active, $9.4 \%$ as active and $17.3 \%$ as highly active. $1 \%$ of the children in the age group of 8 years are active, $8.3 \%$ are active and $21.7 \%$ are highly active. $0,8 \%$ of 9 year-olds are sometimes active, while $8,7 \%$ are active and $19,7 \%$ are active. Of the children in the 10 years age group, $1.8 \%$ were active at times, $9.4 \%$ were active and $11 \%$ were very active. In this study, the subjects with very low and low physical activity levels were not found. 
Table 5. Physical activity levels of children and correlation analysis according to some variables

\begin{tabular}{|c|c|c|c|c|c|c|c|c|}
\hline & & $\begin{array}{c}\text { Physical } \\
\text { activity level }\end{array}$ & $\begin{array}{l}\text { Body Mass } \\
\text { Index }\end{array}$ & $\begin{array}{c}\text { Daily Sleep } \\
\text { Duration }\end{array}$ & $\begin{array}{c}\text { Daily TV } \\
\text { Viewing Time }\end{array}$ & $\begin{array}{c}\text { Daily Computer } \\
\text { or Smartphone } \\
\text { Usage }\end{array}$ & $\begin{array}{c}\text { Transportation } \\
\text { to School }\end{array}$ & $\begin{array}{c}\text { The habit of } \\
\text { consuming } \\
\text { snacks }\end{array}$ \\
\hline \multirow{2}{*}{ Body Mass Index } & $r$ &,$- 730^{* *}$ & & & & & & \\
\hline & $\mathrm{p}$ & 000 & & & & & & \\
\hline \multirow{2}{*}{ Daily Sleep Duration } & $\mathrm{r}$ &,- 048 &, 049 & & & & & \\
\hline & $\mathrm{p}$ & ,283 & ,266 & & & & & \\
\hline \multirow{2}{*}{$\begin{array}{c}\text { Daily TV Viewing } \\
\text { Time }\end{array}$} & $\mathrm{r}$ & 020 &, 012 &, $209^{* *}$ & & & & \\
\hline & $\mathrm{p}$ & ,673 & ,794 & ,000 & & & & \\
\hline \multirow{2}{*}{$\begin{array}{l}\text { Daily Computer or } \\
\text { Smartphone Usage }\end{array}$} & $\mathrm{r}$ &,$- 125^{*}$ & ,048 &,- 058 &,$- 285^{* *}$ & & & \\
\hline & $\mathrm{p}$ & 027 & ,391 & ,305 &, 000 & & & \\
\hline \multirow{2}{*}{$\begin{array}{l}\text { Transportation to } \\
\text { School }\end{array}$} & $\mathrm{r}$ &,- 044 &,- 001 &,- 031 & ,092 &, $149^{* *}$ & & \\
\hline & $\mathrm{p}$ & ,324 & ,974 & ,490 &, 053 & ,008 & & \\
\hline \multirow{2}{*}{$\begin{array}{l}\text { The habit of } \\
\text { consuming snacks }\end{array}$} & $\mathrm{r}$ &,- 046 & ,002 &,- 040 &,$- 106^{*}$ &,$- 197^{* *}$ &, $124^{* *}$ & \\
\hline & $\mathrm{p}$ & ,302 & ,965 & ,369 &, 026 &, 000 &, 005 & \\
\hline \multirow{2}{*}{$\begin{array}{l}\text { The habit of playing } \\
\text { in the playground or } \\
\text { in the street }\end{array}$} & $\mathrm{r}$ &,$- 094^{*}$ & ,082 &,$- 128^{* *}$ &,- 086 &, $111^{*}$ & 019 &, $121^{* *}$ \\
\hline & $\mathrm{p}$ & 034 & 066 & 004 & ,071 & ,048 & ,668 &, 006 \\
\hline
\end{tabular}

$\mathrm{p}<0,05^{*} \quad \mathrm{p}<0,01^{* *} \quad \mathrm{p}<0,001 * * *$

Table 6. Percentage results of physical activity levels by age groups

\begin{tabular}{|c|c|c|c|c|c|}
\hline & & $\begin{array}{c}\text { Somewhat Active } \\
7500-9999 \text { steps }\end{array}$ & $\begin{array}{c}\text { Active } \\
10000-12499 \text { steps }\end{array}$ & $\begin{array}{c}\text { Highly active } \\
>12500\end{array}$ & Total \\
\hline \multirow{2}{*}{7 years old } & $\mathrm{N}$ & 2 & 48 & 88 & 138 \\
\hline & $\%$ & $0,4 \%$ & $9,4 \%$ & $17,3 \%$ & $27,2 \%$ \\
\hline \multirow{2}{*}{8 yaş } & $\mathrm{N}$ & 5 & 42 & 110 & 157 \\
\hline & $\%$ & $1,0 \%$ & $8,3 \%$ & $21,7 \%$ & $30,9 \%$ \\
\hline \multirow{2}{*}{9 years old } & $\mathrm{N}$ & 4 & 44 & 52 & 100 \\
\hline & $\%$ & $0,8 \%$ & $8,7 \%$ & $10,2 \%$ & $19,7 \%$ \\
\hline \multirow{2}{*}{10 years old } & $\mathrm{N}$ & 9 & 48 & 56 & 113 \\
\hline & $\%$ & $1,8 \%$ & $9,4 \%$ & $11,0 \%$ & $22,2 \%$ \\
\hline \multirow{2}{*}{ Total } & $\mathrm{N}$ & 20 & 182 & 306 & 508 \\
\hline & $\%$ & $3,9 \%$ & $35,8 \%$ & $60,2 \%$ & $100,0 \%$ \\
\hline
\end{tabular}

\section{Discussion and Conclusions}

Physical activity is an important factor in children's normal growth and development process. Physical activity is one of the vital elements in the development of community health. Health habits are also gained at an early age and developed later. Therefore, disease prevention programs should be started at this age. The physical activity habit plays an important role as a preventive factor in childhood obesity, which is the imbalance between energy intake and expenditure. It is important to evaluate physical activity in pre-adolescent children. In addition to physical activity, daily living conditions of children (such as nutrition, time spent on television and computer, access to school, feeding and transportation methods) are of great importance [17].

When the physical activity levels of the children were examined; $3,9 \%$ reported that they were active at some times, $35,8 \%$ had an active life and $60,2 \%$ were highly 
active. No children with sedentary or low levels of physical activity were observed in the sample group. According to the Body Mass Index; 5.9\% were underweight, $61.8 \%$ were borderline, $31.1 \%$ were healthy weighted and $1.2 \%$ were overweight.

It was determined that the children in all age groups who participated in our study slept around 8 hours on average. Table 4 shows that daily TV viewing time is about 2 hours and the duration of viewing decreases with age. The daily use of computers and smartphones is between 2-3 hours on average and this period increases with the age. The number of children walking to school and the number children who use a way of transportation are nearly the same and there is no difference between the age groups in terms of transportation. There was a significant difference in terms of playing in the playground after school. This difference is due to the age group 7 years and 10 years.

A significant relationship was found between physical activity level and body mass index. According to our study, a significant relationship was found between daily TV viewing time and physical activity level. A significant relationship was determined between daily computer or smartphone usage time and physical activity level.

Yilmaz's study about sleep in children states that the duration varies from person to person and on average they should sleep for a minimum of 6-7 hours [18]. Saygin and Bayrakdar found that children have a sleep time between 8-10 hours [6]. The studies show that children have a daily television watching time of 2 hours Al-hazza [19], Pearson[20], Brown [21] , Gomez[22] Saygin [6]. Junger reported in his study that primary school children have an orientation towards obesity because of their irregular diet and inability to burn the energy taken [23]. Simsek stated in his study that children of primary school age usually watch television around 3-4 hours per day [7].

Belton reported the height values of children aged between 6 and 9 years as $1.31 \mathrm{~m}$, and body weight as 29.2 $\mathrm{kg}$, and their BMI as $17 \mathrm{~kg} / \mathrm{m}^{2}$ [24]. Duncan stated the weight of children aged 8-11 years, whose weight is 33.3 $\mathrm{kg}$. The height is $1.39 \mathrm{~m}$ and their BMI is $17.5 \mathrm{~kg} / \mathrm{m}^{2}[25]$. Kolle found at the height of 9-year-old children to be 1.39 $\mathrm{m}$, body weight to be $33.9 \mathrm{~kg}$ and their BMI to be 17.2 $\mathrm{kg} / \mathrm{m}^{2}$ [26]. Deforch found the BMI of children of 6- 10 years of age is $15.7 \mathrm{~kg} / \mathrm{m}^{2}$ [27]. Gorely found it to be 17.5 $\mathrm{kg} / \mathrm{m}^{2}$ for children 7-11 years old [28] and Ridgers reported the height of children to be $1.33 \mathrm{~m}$, body weight to be 31.9 $\mathrm{kg}$ and BMI to be $17.8 \mathrm{~kg} / \mathrm{m}^{2}$ [29]. Catherine stated that the weight and BMI values increase with age in children aged 10-12 [30]. Chin demonstrated that the BMIs of boys were $17.5 \mathrm{~kg} / \mathrm{m}^{2}$ in their study of 2443 whose average age was 9,2 [31], and Komata conducted a study with children aged 10 , at 6-month intervals, stated that an increase in height and weights of boys is observed with age [32].

Le masurier shows that there is a negative correlation between BMI and weight and physical activity level [33]. Belton (2010) states that the physical activity in boys of 6-9 years is 16821 steps [24]. Duncan shows this as 12263 steps in boys between 8-11 years old [25]. Deforche found this as 12263 steps in 6-10 year-old boy [27] and Duncan's physical activity level as the gold level. Gorely stated that the daily physical activity levels of children is 9789 steps [28]. Locke [34] in his study named "how many steps are enough?" displayed this as 5000 steps and the below this level as sedentary, between 5000-7459 steps as low active group, between 7500-9999 steps slightly active, between 10000-12499 active and 12500 steps and high levels of active. Locke stated that children with daily physical activity steps of 12000-15000 are healthier and have more positive BMI levels[35]. Le Masurier mentions that from childhood on to old age, physical activity steps and levels show a steady decrease [33]. Locke said that children have an average of 8000-12000 steps [36]. Raustorp and Ludvigsson argued that children have a daily level of 15,991-16,273 steps [37], Cox shown the daily average steps of boys to be 15606 [38]. In their study, Locke and Bassett stated that 5000 steps and lower mean a low quality of life, the quality of life between 5000 and 7499 steps is at sedentary level; between 7500-9999 steps is a sign of low quality of life; 10000 steps and above reflects a good quality of life and 12500 is good. Locke says that males have an average 13000 daily step-by-step level [16], while Craig men have an average of 12259 steps per day [39]. Duncan (2006) found that children have a 14124-day step level [25].

According to our research; for the protection or enhancement of physical activity; it is recommended to make physical activity more fun and to create activities appropriate for age groups. The duration of use of television, computer and smartphone should be reduced, and regular sleep times should be encouraged. Foods sold in school canteens should be inspected and selling of food such as soda and chips should be banned. Increasing the number of physical activity areas in playgrounds in schools and after-school plays an important role in children's physical activity habits.

In conclusion, it can be said that the body mass indexes of the children between 7-10 years of age are healthy and their physical activity levels are generally active and highly active level.

\section{REFERENCES}

[1] Zorba E., Saygin O. (2009) Fiziksel Aktivite ve Fiziksel Uygunluk, Bedray Publishing, Istanbul, October.

[2] Bek, N. (2008). Fiziksel aktivite ve sagligimiz. Ministry of Health Publications(730).

[3] Aksoydan, E., Cakir, N. (2011). The assessment of the nutritional habits, physical activity levels and body mass indexes of adolescents. Gulhane Medicine Magazine, 53264-270. 
[4] Pitta F., Troosters T., Probst V.S. Sproit M.A., Decramer M., Gosselink R.; Koah'ta anketler ve hareket sensörleri ile günlük yaşamdaki fiziksel aktiviteyi belirleme, European respiratory journal, Volume 1, Issue 3, 2006

[5] Baltaci, G., Tedavi, F. (2008). Cocuk ve Spor. Ankara: Hacettepe University-Faculty of Health Sciences, Department of Physical Therapy and Rehabilitation, First Edition: February.

[6] Saygin, O., Bayrakdar, A. (2012). Evaluation of body mass index and basal metabolic rate, step number of days in boys children. Journal of Human Sciences, 9(1), 372-384.

[7] Simsek, F. (2005). Ankara'da bir ilkogretim okulu ve lisede obezite sikligi Obesity prevalence in a primary school and a high school in Ankara. Ankara University Faculty of Medicine Magazine, 58(4).

[8] Donohoue, P.A. (2004). Obesity. In: Nelson textbook of pediatrics. Eds: Behrman, R.E., Kliegman, R.M., Jenson, H.B., 17th ed. Philadelphia: W.B. Saunders, 173-177.

[9] Popkin, B. M. (2001). The nutrition transition and obesity in the developing world. The Journal of Nutrition, 131(3), 871S-873S.

[10] Birch, L. L., \& Fisher, J. O. (1998). Development of eating behaviors among children and adolescents. Pediatrics, 101(Supplement 2), 539-549.

[11] Martínez-González, M. Á., Martinez, J. A., Hu, F. B., Gibney, M. J., Kearney, J. (1999). Physical inactivity, sedentary lifestyle and obesity in the European Union. International journal of obesity, 23(11), 1192.

[12] Gunes, Z. (2005). Spor ve beslenme. Ankara: Nobel Publishing Distribution.

[13] Atamer, Y., Erden, A. C., Demir, B., Kocyigit, Y.,Atamer, A. (2004). The relationship between plasma levels of leptin and androgen in healthy and preeclamptic pregnant women. Acta obstetricia et gynecologica Scandinavica, 83(5), 425-430.

[14] Larsson, S. C., Orsini, N., \& Wolk, A. (2007). Body mass index and pancreatic cancer risk: a meta-analysis of prospective studies. International journal of cancer, 120(9).

[15] Cole, T. J., Bellizzi, M. C., Flegal, K. M., \& Dietz, W. H. (2000). Establishing a standard definition for child overweight and obesity worldwide: international survey. Bmj, 320(7244), 1240.

[16] Locke T.C., Bassett DR J., Rutherford W.J., Ainsworth B.E., Chan C.B., et.all. (2008) BMI-referenced cut points for pedometer-determined steps per day in adults, Journal physical Activity Health, 5 suppl 1: pp.26-39.

[17] Saygin, O., Babayigit Irez, G., Bayrakdar, A., Gur, F. (2012). Erkek cocuklarin gunluk yasam kosullari, adim sayilari ve vucut kompozisyonlarının incelenmesi, International refereed Academic Sports Health \& Medical Sciences Magazine, Issue 3, Volume 2.

[18] Yilmaz, G., Gurakan, B. (2011), Cocuklukta Uyku Duzeni Sorunlari, Sted, Volume 11, Issue 8, p.289

[19] Al-Hazaa, H. M., Abahussain, N. A., Al-Sobayel, H. I., Qahwaji, D. M., \& Musaiger, A. O. (2011). Physical activity, sedentary behaviors and dietary habits among Saudi adolescents relative to age, gender and region. International
Journal of Behavioral Nutrition and Physical Activity, 8(1), 140.

[20] Pearson, N., Ball, K., \& Crawford, D. (2011). Mediators of longitudinal associations between television viewing and eating behaviours in adolescents. International journal of behavioral nutrition and physical activity, 8(1), 23.

[21] Brown, H. S., Pérez, A., Mirchandani, G. G., Hoelscher, D. M., \& Kelder, S. H. (2008). Crime rates and sedentary behavior among 4th grade Texas school children. International Journal of Behavioral Nutrition and Physical Activity, 5(1), 28.

[22] Gomez, L. F., Parra, D. C., Lobelo, F., Samper, B., Moreno, J., Jacoby, E., Borda, C. (2007). Television viewing and its association with overweight in Colombian children: results from the 2005 National Nutrition Survey: A cross sectional study. International Journal of Behavioral Nutrition and Physical Activity, 4(1), 41.

[23] Junger, M., \& van Kampen, M. (2010). Cognitive ability and self-control in relation to dietary habits, physical activity and bodyweight in adolescents. International Journal of Beha vioral Nutrition And Physical Activity, 7(1), 22.

[24] Belton S., Brady P., Megan S., Woods C. (2010) Pedometer step count and BMI of Irish primary school children aged 6-9 years, Preventive Medicine, 50, 4, 189-192.

[25] Duncan M.J., Al-Nakeeb Y., Woodfield L., Lyons M. (2007) Pedometer determined physical activity levels in primary school children from central England, Preventive Medicine, 416-420.

[26] Kolle E., Stene-Johannessen J., Andersen B.L., Anderssen S.A. (2009) Seasonal variation in objectively assessed physical activity among children and adolescents in Norway: a cross sectional study, International Journal of Behavioral Nutrition and Physical Activity, 29;6:36.

[27] Deforche B., De Bourdeaudhuij I., D'hondt E., Gardon G. (2009) Objectively measured physical activity, physical activity related personality and body mass index in 6- to 10-yr-old children: a cross-sectional study, International Journal of Behavioral Nutrition and Physical Activity, 10.1186/1479-5868-6-25.

[28] Gorely T., Nevill M.E., Morris G.J., Stensel D.J., Nevill A. (2009) Effect of a schoolbased intervention to promote healthy lifestyles in 7-11 year old children, International Journal of Behavioral Nutrition and Physical Activity, $10.1186 / 1479-5868-6-5$.

[29] Ridgers D.N., Stratton G., Fairclough S.J., Twisk J.W.R. (2007) Long-term effects of a playground markings and physical structures on children's recess physical activity levels, Preventive Medicine, 44(5), 393-397.

[30] Catherine S., Helaine R.H., Alison E., Matthew W., Lindsay F., Carlos A., Graham A. (2000) Activity, dietary intake, and weight changes in a longitudinal study of preadolescent and adolescent boy and girls, Pediatrics, 105, (4).

[31] Chin M.K., Girandola R.N., Yang J., Cruz A., Liu Y.K. (2002) The body mass index and body composition of Hong Kong school children. The 44. Ichper-SD World Congress, Taipei, Taiwan, p.17.

[32] Komata R. (2002) Grip strength of elementary school 
children. The 44. ishper-SD World Congress, Taipei, Taiwan, p.414-421.

[33] Le Masurier G.C., Sidman C.L., Corbin C.B. (2003) Accumulating 10000 steps: does this meet current physical activity guidelines?, Res Q Exercise Sport, Dec; 74(4): 38994.

[34] Locke T.C., Bassett DR J. (2004) How many steps-day enough? Preliminary pedometer indices for public health, Sports Medicine, 34(1):1-8.

[35] Locke T.C., Hatano Y., Pangrazi R.P., Kang M. (2008) Revisiting "how many steps are enough?" Medicine Science Sports Exercise, Jul; 40 (7suppl): pp.37-43.

[36] Locke T.C., Johnson W.D., Katzmarzyk P.T. (2010) Accelerometer-determined stepsday in U.S. children and Youth, Medicine Science Sports Exercise, 42 (12): 2244-50.

[37] Raustorp A., Ludvigsson J. (2007) Secular trends of pedometer-determined physical activity in Swedish school children, Acta Pediatric, 96(12): 1824-8.

[38] Cox M., Schofield G., Greasley N., Kolt G.S. (2004) Pedometer steps in primary school-aged children: a comparison of school-based and out-of-school activity, Sports Medicine, 34(1):1-8.

[39] Craig C.L., Cameron C., Griffiths J.M., Locke T.C. (2010) Descriptive epidemiology of youth pedometer-determined physical: Canplay, Medicine Science Sports Exercise, 42(9):1639-43. 